\section{DA HUMILDADE À FORC̣A: imagens de Trajano na literatura do Principado}

From Humility to Strength: Images of Trajan in The Literature of the Principate
Andrea Lúcia Dorini de Oliveira Carvalho ROSSI

(D) andrea.dorini@unesp.br

Universidade Estadual

Paulista,

Assis, SP, Brasil

\section{RESUMO}

O objetivo deste artigo é fazer alguns apontamentos sobre a imagem do Imperador Trajano como optimus princeps a partir da literatura produzida no Principado Romano. As obras analisadas são as produzidas por Suetônio, Plínio, o Jovem, Dion de Prusa e Dion Cássio e que permitem identificar a construção de imagens dos dois imperadores de forma dicotômica e antagônica como a de Trajano a partir de seu antecessor, Domiciano. Estas posturas antagônicas são abordadas, a partir destas obras, por meio de dois elementos fundamentais para um governante do Império Romano: a sua relação com o Senado e a sua liderança perante o Exército.

Palavras-chave: Trajano, Literatura, Principado, Senado, Exército.

\begin{abstract}
The purpose of this article is to make some notes on the image of Emperor Trajan as an optimus princeps from the literature produced in the Roman Principality. The analyzed works are those produced by Suetonius, Pliny the Younger, Dio of Prusa and Cassius Dio and that allow to identify the construction of images of the two emperors in a dichotomous and antagonistic form like that of Trajan from his predecessor, Domitian. These antagonistic positions are approached, based on these works, through two fundamental elements for a ruler of the Roman Empire: his relationship with the Senate and his leadership before the Army.
\end{abstract}

Keywords: Trajano, Literature, Roman Principality, Senate, Army. 
proposta deste artigo surgiu de um convite da Profa. Dra. Margarida Maria de Carvalho, para participar como palestrante do I Colóquio Internacional do

Grupo do Laboratório de Estudos sobre o Império Romano da Unesp-Franca, proporcionando o debate sobre a Memórias e Mortes dos Imperadores Romanos (I d.C a VI d.C.) como integrante da mesa intitulada "Memórias e mortes da dinastia Antonina (Séc. II d.C.)" composta também pelo Prof. Dr. Deivid Valério Gaia (UFRJ) e pela Profa. Dra. Dominique Monge (UNESP/Franca).

Diante do tema proposto, a opção adotada foi escrever sobre o optimus princeps Trajano e fazer alguns apontamentos sobre as imagens do Imperador Trajano presentes em algumas fontes literárias. A abordagem adotada foi estruturada a partir de uma relação possível, dicotômica e imediata, a partir da documentação utilizada. Essa abordagem dicotômica estabelece um paralelo entre Domiciano (81 a 96 E.C.), último imperador da Domus Flávia (69 a 96 E. C.), e o segundo imperador da Domus Antonina (96 a 192 E. C.), Trajano (98 a 117 E.C.). Com este paralelo, foi estabelecido um recorte a partir das obras literárias utilizadas que possibilitam estabelecer algumas características dos dois governantes de forma antagônica. Com isso, dois elementos serão destacados e que são inerentes ao poder dos Imperadores Romanos: a relação com o Senado e com o Exército.

É importante salientar que há o conhecimento de que alguns pesquisadores brasileiros se debruçam ou se debruçaram sobre o tema aqui proposto. No entanto, algumas perspectivas aqui adotadas não foram propriamente abordadas. Tiago Stadler e Alex Costa produziram alguns trabalhos sobre a documentação pliniana e a imagem do Imperador Trajano, principalmente levando-se em consideração a documentação epistolar. Nelson Bondioli também é um dos autores aqui referenciados. Diante das discussões existentes, optou-se por seguir um caminho mais específico de análise das imagens em fontes que extrapolam a abordagem dada pelos autores referenciados acima, sem desconhecê-los.

\section{Trajano e Domiciano e suas relações com o Senado e o Exército}

Os dois primeiros séculos do Principado Romano são marcados por imagens, por vezes contraditórias, que envolvem a maioria dos imperadores romanos, desde Augusto até Trajano, e as suas relações com os vários e complexos segmentos da sociedade romana. Estas imagens contraditórias são decorrentes das mudanças sociais, econômicas, políticas e culturais que pululam durante estes dois séculos.

Ao analisar algumas das obras literárias que são escritas neste contexto e outras que escrevem sobre o período em questão, pode-se chegar a algumas premissas. Em sua maioria, os autores destas obras estão diretamente envolvidos nos meios políticos e sociais compostos por elites romanas, sejam estas provinciais, itálicas ou do próprio Lácio, e são, simultaneamente, produtores e condutores de um complexo imaginário social imperial. Portanto, é de fundamental importância analisar estas obras literárias enquanto veículos portadores de discursos que possam representar elementos da identidade e da alteridade sócio-cultural romanos. Estas identidades e alteridades 
assumem um caráter público evocando um conjunto de representações políticas e administrativas ligadas à imagem do Senado e do Princeps de Roma.

O Imperador Trajano, depois de Augusto, é um dos imperadores mais referenciados pela literatura, pela estatuária e pela iconografia monumental. Estas últimas mais abundantes do que a primeira. Em relação à literatura, temos autores que produzem obras no período de governo de Trajano, mas que não abordam diretamente o período de seu governo. Tácito, Suetônio e Dion de Prusa são alguns dos exemplos.

Na segunda metade do II século, a obra História Romana, de Dion Cássio, nos apresenta elementos mais específicos sobre o período do governo de Nerva e Trajano no livro 68, escrito por volta de 70 a 80 anos a posteriori. Também é possível se analisar características deste imperador ao se estudar o Livro X, das Cartas de Plínio, o Jovem e ao seu Panegírico de Trajano. Estas obras nos possibilitam análises complementares sobre as imagens literárias de Trajano, seja por relatos diretos como é o caso de Plínio, o Jovem e Dion Cássio, seja por referências indiretas.

Um dos vários exemplos das referências indiretas está presente em Suetônio, ao final de sua obra $A$ Vida dos Doze Césares na biografia de Domiciano, sobre a ocasião de sua morte:

As pessoas receberam a notícia de sua morte com indiferença, mas os soldados estavam sofrendo a sua perda e queriam chamá-lo de Divus Domiciano, enquanto também se preparavam para vingá-lo, Ihes faltava um líder. O que foi feito mais tarde, com a execução de seus assassinos.

Os Senadores, ao contrário, estavam em júbilo, se apressaram em preencher a Cúria, onde não se refrearam ao se referirem à morte do imperador com gritos e insultos. Trouxeram as escadas e seus escudos e derrubaram suas imagens diante de todos; finalmente, eles aprovaram um decreto de que suas inscrições deveriam ser apagadas em todos os lugares, e todo registro sobre ele deveria ser eliminado.

Poucos meses antes de ser assassinado, um corvo havia pousado no Capitólio e gritado: "Tudo ficará bem!", um presságio que alguns interpretaram da seguinte forma:

"Recentemente no Cume Tarpeio um corvo pousou, 'Está bem' não pôde dizer, disse: 'Ficará (Erit!)'.”

O próprio Domiciano, é dito, sonhou que uma corcunda dourada teria crescido em suas costas, e considerou este sonho como um sinal infalível de que a condição do império seria mais feliz e mais próspera depois de seu tempo; e isso em breve foi mostrado como verdadeiro pela retidão e domínio moderado dos sucessores. $(23,1-2)$

Suetônio evoca as posições contraditórias entre o Senado e o Exército em relação ao imperador e a obrigação militar dos soldados pelo seu líder. Ao fazer referência a dois presságios, deixa claro que o destino de Roma seria melhor após Domiciano. Esta passagem tem sido referenciada pela historiografia como uma das que exemplificam 
a resistência política do Senado em relação ao governo de Domiciano, deixando clara a posição perante os governos sucessores de Nerva e Trajano.

Essa resistência política em relação a Domiciano, narrada por Suetônio sobre a sua damnatio memoriae, também é reforçada por Dion Cássio no início do livro LXVIII sobre a transição entre os governos de Domiciano, Nerva e de Trajano.

Depois de Domiciano, os romanos nomearam o imperador Nerva Cocceius. Por causa do ódio sentido por Domiciano, suas imagens, muitas das quais eram de prata e muitas de ouro, foram derretidas; e dessa fonte grandes quantias de dinheiro foram obtidas. Também os arcos, dos quais um número muito grande estava sendo erguido para esse homem, foram derrubados. (LXVIII, 1.1)

É importante destacar estas passagens sobre Domiciano já que promovem elementos de contraponto para as construções discursivas textuais sobre Trajano que, constantemente, aparece como um governante com características opostas ao seu antecessor. Essa dicotomia pode ser vista, também na História Romana, em uma passagem que Trajano é retratado como conciliador e próximo ao Senado.

Trajano, antes de se tornar imperador, sonhara com a seguinte natureza. Ele sonhou que um homem velho, vestindo uma toga e uma roupa com bordas roxas e uma coroa na cabeça, como o Senado é representado em pinturas, imprimiu um selo nele com um anel de dedo, primeiro no lado esquerdo do pescoço e depois à direita. Quando se tornou imperador, ele enviou uma carta ao Senado, escrita com sua própria mão, na qual declarou, entre outras coisas, que não mataria nem privaria nenhum bom homem; e ele confirmou isso por juramentos, não apenas na época, mas também mais tarde. (LXVIII, 5.1-2)

Nestas referências aos dois governantes, fica clara a relação imagética que estabelecem com o Senado conforme as narrativas apresentadas: Domiciano era odiado pelo Senado e Trajano teria mantido uma relação harmônica e de aproximação política com este mesmo colégio.

Além das questões relacionadas aos apoios políticos e a boa relação com o Senado, Trajano também foi relacionado com Domiciano em um dos feitos bélicos mais conhecidos do I Século do Principado: As Guerras Dácicas.

Tanto em Suetônio como em Dion Cássio, é possível identificar narrativas sobre o episódio bélico entre os dácicos e os romanos.

Suetônio, sobre a guerra contra os dácicos, escreve apenas que Domiciano teria conduzido duas campanhas, ambas por dois generais que teriam liderado estas investidas.

Ele empreendeu suas campanhas em parte sem provocação e em parte por necessidade. Contra os Chatti foi desnecessária, 
enquanto contra os sármatas foi justificada pela destruição de uma legião com seu comandante. Ele realizou duas campanhas contra os dácicos, a primeira quando Oppius Sabinus, um excônsul, foi derrotado, e a segunda na derrubada de Cornelius Fuscus, prefeito da guarda pretoriana, a quem ele confiara a condução da guerra. Após várias batalhas de variáveis sucessos, ele comemorou um triunfo duplo sobre os Chatti e os dácicos. Suas vitórias sobre os sármatas, ele comemorou apenas pela oferta de uma coroa de louros a Júpiter do Capitólio. (Suetônio, Dom., 6, 1)

Podemos analisar as Guerras Dácicas com maiores propriedades narrativas à luz das fontes textuais na História Romana de Dion Cássio, que tem sido a maior referência. Se buscarmos uma narrativa contínua e biográfica sobre os imperadores Domiciano e Trajano, temos que, obrigatoriamente, trazer Dion Cássio como a principal fonte literária que nos chegou de forma muito fragmentada. O historiador, em sua História Romana, nos livros LXVII e LXVIII, narra as trajetórias de Domiciano e de Trajano, herdeiro de Nerva, além de ressaltar a liderança do Antonino na Guerra Dácica. Apenas uma única frase do próprio comentário de Trajano sobreviveu; a este fragmento órfão podemos acrescentar os resquícios da obra de Dion Cassio, escritos pela primeira vez cerca de 80 anos após a morte de Trajano. As passagens em questão são preservadas em resumos (os "epítomos") escritos por Johnnes Xiphilinus, um monge do século XI de Constantinopla, e em trechos de trocas diplomáticas que datam do período bizantino.

Dion Cássio traz maiores detalhes sobre a campanha de Domiciano contra os dácicos e descreve características que não seriam inerentes a um imperator, ou seja, um líder do Exército e posturas adequadas na condução de campanhas bélicas.

Naquela época, os romanos se envolveram em uma guerra muito séria com os dácicos, cujo rei era Decébalo. Esse homem era perspicaz em sua compreensão da guerra e também perspicaz na guerra; ele julgou bem quando atacar e escolheu o momento certo para recuar; ele era especialista em emboscadas e mestre em batalhas campais; e ele sabia não apenas como acompanhar bem uma vitória, mas também como administrar bem uma derrota. Por isso, ele se mostrou um antagonista digno dos romanos por um longo tempo. (...)

Domiciano, então, fez uma expedição contra esse povo, mas não participou ativamente do conflito. Em vez disso, ele permaneceu em uma das cidades da Moésia, entregando-se a uma vida tumultuada, como costumava ser. Pois ele não era apenas indolente de corpo e tímido de espírito, mas também muito desleixado e lascivo com mulheres e meninos. Ele, portanto, enviou outros para conduzir a guerra (grifo nosso) e, na maioria das vezes, conseguiu o pior.

Decébalo, o rei dos dácicos, fazia aberturas para Domiciano, prometendo-Ihe paz; mas Domiciano enviou Fuscus contra ele com uma grande força. 
(...) Quando os soldados que fizeram a campanha com Fuscus pediram a Domiciano que os liderasse. (LXVII, 6, 1-6)

Dion Cássio, em um trecho posterior, ainda coloca em questão a possível vitória de Domiciano contra os dácicos.

Domiciano, derrotado pelos Marcomani, fugiu e rapidamente enviou mensagens a Decébalo, rei dos Dácicos, induziu-o a fazer uma trégua, embora ele próprio até agora tivesse se recusado a conceder uma resposta aos pedidos frequentes de Decébalo. E assim Decébalo aceitou suas propostas, pois havia tido grandes perdas; contudo, ele não desejava realizar uma conferência pessoalmente com Domiciano, mas enviou Diegis com os homens, para lhe dar as armas e alguns cativos, que, ele fingiu, eram os únicos que ele tinha. 3 Quando isso foi feito, Domiciano colocou um diadema na cabeça de Diegis, como se ele tivesse realmente conquistado e pudesse dar aos dacicos quem ele quisesse ser seu rei. Aos soldados ele concedeu honras e dinheiro. E, como se tivesse ganho uma vitória, ele enviou a Roma, entre outras coisas, enviados de Decébalo e também uma carta do rei, como ele alegou, embora os boatos declarassem que ele a forjara. (LXVII, 7)

Estas referências a Domiciano são apenas algumas das quais evocam o último imperador flaviano e suas posturas diante de campanhas bélicas e o seu afastamento de contato direto com o Exército em campo de batalha.

As campanhas anteriores contra os dácicos, assim como contra os germânicos por meio do Danúbio por Domiciano, foram parcialmente bem sucedidas, mas a situação teria ficado instável nesta fronteira nordeste do Império Romano. O rei dácico Decébalo, que havia permanecido no poder como um entrave na visão dos romanos, havia despendido a maior parte da última década preparando seu exército de acordo com os modelos romanos. Graças às campanhas promovidas por Domiciano, Decébalo fortificou as fronteiras de seu território e criou obstáculos para o domínio romano na região.

Ainda sobre a Guerra Dácica e a postura de Trajano, é possível identificar na narrativa de Dion Cássio características divergentes em posturas e decisões nas campanhas.

Depois de passar algum tempo em Roma, ele fez uma campanha contra os Dácicos; pois levou em conta os feitos passados e ficou entristecido com a quantidade de dinheiro que recebiam anualmente, e também observou que o poder e o orgulho deles estavam aumentando. Decébalo, sabendo de seu avanço, ficou assustado, pois sabia muito bem que na ocasião anterior não havia conquistado os romanos, mas Domiciano, enquanto agora lutaria contra os romanos e Trajano, o imperador. Trajano foi mais notável por sua justiça, por sua bravura e pela simplicidade de seus hábitos. Ele tinha um corpo forte, estando no quadragésimo segundo ano em que começou a governar, de modo que em toda campanha trabalhava quase tanto quanto os outros; e 
seus poderes mentais eram os mais altos, de modo que ele não tinha nem a imprudência da juventude nem a lentidão da velhice. 4 Ele não invejou nem matou ninguém, mas honrou e exaltou todos os homens bons, sem exceção, e, portanto, não temeu nem odiou nenhum deles. Para as calúnias, ele prestava muito pouca atenção e não era escravo da raiva. Ele se absteve igualmente do dinheiro de outros e de assassinatos injustos. (LXVIII, 6)

Dion de Prusa, denominado postumamente como Dion Crisóstomo, em seu Discurso XII - O Discurso Olímpico, datado provavelmente de 101 d.C., também pode ser tratado como uma fonte de referência indireta sobre as práticas militares de Trajano, mais especificamente sobre as Guerras Dácicas, feito militar que é mote de comparação constante com o seu antecessor, Domiciano. Neste discurso, Dion de Prusa relata a sua passagem sobre o Danúbio e o encontro com o exército de Trajano. Pode-se ver nesse discurso as posições assumidas por Dion de Prusa em relação às posturas de Trajano no conflito com os Getas, chamados de Dácicos pelos romanos. Dion de Prusa faz, em seu relato, uma analogia de seu papel junto ao exército romano com a função de conselheiro, assim como Ulisses o fez na Guerra de Tróia. Em sua última referência "desarmado, sem nenhum elmo nem escudo ou lança" faz uma referência clara a esta função quando cita a llíada, de Homero $(21,50)$.

Ao continuar a descrever a reunião do exército romano na Dácia, o autor bitiniano valoriza a sua organização e seu armamento indicando a força bélica sob a liderança de Trajano. Ao exibir as suas incapacidades, Dion de Prusa aborda, de forma retórica, as funções exercidas na composição das legiões romanas, especificamente a organização do exército sob o comando de Trajano no período das Guerras Dácicas. Neste discurso, Dion de Prusa também descreve o seu encontro com o exército romano engrandecendo as formas de organização das legiões junto ao Danúbio.

Eu, que era inútil para tais coisas, vim entre os homens que não eram estúpidos, mas não sentiam nenhum prazer em ouvir discursos, pois estavam tensos assim como cavalos de corrida em sua linha de partida, desgastados pelo atraso e em seus excitamentos e na ânsia de galgar a terra com suas patas. Lá se poderia ver em toda parte espadas, em toda parte couraças, em toda parte lanças, e o lugar inteiro estava aglomerado com cavalos, com armas, e com homens armados. Completamente sozinho, eu apareci no meio deste anfitrião poderoso, perfeitamente imperturbado e o mais calmo observador da guerra, fraco no corpo e avançado nos anos, sem carregar 'um cetro' dourado ou as faixas sagradas de algum deus e chegando ao acampamento em uma viagem reforçada para ganhar liberdade, mas desejando ver homens fortes afirmandose pelo império e pelo poder, e seus oponentes por liberdade e pelas terras. Então, não porque eu me acovardei do perigo - que ninguém pense isso - mas porque eu me ocupei em relembrar um antigo voto, eu retomei meu caminho em direção a vocês, sempre considerando que as coisas divinas têm a maior 
importância e são mais rentáveis do que as coisas humanas, contudo estas também podem ser importantes. (XII.19-21)

Esta narrativa teria ocorrido antes de Trajano retornar a Roma, em 99 d.C., para ser aclamado imperador, quando teria despendido um período de tempo para verificar a disposição do inimigo, investigando as fortificações, assegurando-se e inspirando-se no preparo para a ofensiva contra a Dácia.

Plínio, o Jovem, em seu Panegírico de Trajano, retrata Trajano como um soldado que também compreendeu a necessidade de fazer arranjos políticos em Roma antes de focalizar sua energia em outra parte.

Estas mesmas descrições podem ser vistas nas representações esculpidas na Coluna de Trajano. As várias ações do exército romano na aproximação dos dácicos e o cerco estabelecido desde o ano de 101 d.C. podem ser analisados à luz das duas fontes. Por ser uma fonte essencialmente simbólica, retórica e de representações alegóricas, Dion de Prusa é muito pouco explorado com esta abordagem.

O estudo da Coluna de Trajano e das Cartas de Plínio, o Jovem, mais especificamente o Livro X e o Panegírico de Trajano, têm trazido várias possibilidades de abordagens para a identificação das muitas facetas atribuídas a este imperador. São estas imagens, às vezes contraditórias e às vezes complementares, que foram constituindo a memória social sobre Trajano. Deve se somar a estas, as fontes materiais como a estatuária, a moedas e as epigrafias.

\section{Optimus Princeps: narrativas sobre a humildade e desprendimento de Trajano}

Algumas obras literárias do Principado, como já apontado, podem trazer elementos imagéticos sobre Trajano como um governante ideal. Plíno, o Jovem e Dion Cássio são as principais obras que trazem este imperador como o melhor dos melhores, o Optimus Princeps.

A principal obra que traz estes elementos é o Panegírico de Trajano de Plínio, o Jovem. Essa peça atribuída ao senador romano em agradecimento à sua indicação como cônsul na província de Ponto-Bitínia, lida ao Senado Romano no ano 100 E.C., tem sido de estudos de várias vertentes científicas desde as abordagens de natureza retórica até seus aspectos políticos e históricos.

Há algumas convergências na definição dos Panegíricos:

eram discursos comuns no âmbito da antiguidade como um todo. O nome pelo qual são chamados pertence à linguagem da retórica grega, sendo designado originalmente como um habitual complemento das assembleias solenes, fundamentado pela oratória e retórica.(...) Tendo a laudatio, sob a forma de elogios aos imperadores, como uma de suas principais características, os discursos panegirísticos procuravam fundamentar a política imperial, transformando-se em eficientes instrumentos propagandísticos, o que remete a um aumento considerável do número de produções deste tipo em um curto intervalo de 
tempo, sendo estes discursos considerados como obrigatórios após algum acontecimento ou atitude "gloriosa" por parte do imperador. (FRANCHI, 2007, p. 100-101)

Esse conceito é amplamente usado e apropriado pela maioria dos estudiosos clássicos que visa analisar esse gênero literário como texto propagandístico pleno de recursos retóricos e de oratória. Nelson Bondioli reforça essa posição em seu texto de tradução para a língua portuguesa ao identificar o seu objeto:

Plínio, o Jovem realiza sua ação de graças, como ele próprio sempre se refere ao que chamamos de Panegírico de Trajano, em setembro do ano 100 E.C., momento em que junto ao seu colega e amigo Cornuto Tértulo, assume o consulado. Nesse sentido, deve-se observar que, em primeiro lugar, o Panegírico de Trajano trata-se, na verdade, de um discurso que após seu pronunciamento perante ao Senado e ao Príncipe, foi subsequentemente alterado/revisado, acrescido e preservado (Cartas 3.13; 3.18) (BONDIOLI, 2017b, p. 19)

O texto de Plínio, o Jovem é, sem sombra de dúvidas, independente das abordagens teóricas que se adote, um agradecimento por um ato administrativo e político de Trajano ao indicar o senador e seu colega como cônsules. O senador também elabora a Gratiarum Actio evocando as grandes características do Imperador Trajano, elemento presente também nos panegíricos e fundamentais em qualquer texto de natureza laudatória. Nesse sentido, o aspecto formal do texto não altera a abordagem discursiva possível. (BONDIOLI; ROSSI, 2018)

A historiografia tem demonstrado algumas análises sobre a presença das vozes discursivas no Panegírico de Trajano, no entanto algumas posições são comuns. Dentre elas, a originalidade do texto e as influências de exempla ou de interlocuções com autores contemporâneos:

Não há um discurso anterior com o qual o Panegírico seja comparável, mas deve muito, particularmente em grande estilo, ao Pro Marcello de Cícero. Plínio descreve e exalta as virtudes de Trajano, denigre Domiciano, e, como Sêneca em sua obra De Clementia, estabelece certos ideais de conduta do princeps (cf. Epist. 3.18.3). Ele tinha uma tarefa delicada, e em alguns tópicos, militar e dinástico, ele tem que ser extremamente circunspecto. Quando ele afeta a independência franca ou mistura brincadeiras com louvor (por exemplo, 59.3-6), recorda as palavras azedas de Tácito ea sola species adulandi supererat 'que era a única marca de adulação ainda não experimentado'. Sem dúvida Trajano mereceu aclamação como o melhor dos imperadores, mas Plínio estraga seu caso, entusiasmando interminavelmente sobre trivialidades e por sua obsessão com Domiciano, com quem Trajano é repetidamente contrastado. Afinal, é uma forma estranha de elogio reiterar que um homem não é um profano, não um sádico, não um megalomaníaco, e de fato Plínio pede desculpas por essas comparações em 53.1 -3, não 
totalmente convincente. À primeira vista, o Panegírico pode parecer exuberantemente otimista, mas ocasionalmente um fio de melancolia profunda é demonstrado. Os maus imperadores podem voltar (veja, por exemplo, 88,9), e o que o Senado sofreu no passado pode sofrer novamente. A perspectiva de Plínio não é totalmente diferente da de Tácito, a quem ele às vezes imitava ou provocava imitação. Mas uma ocasião cerimonial impôs restrições além daquelas que inibiram a liberdade de expressão em geral: os assuntos mais interessantes no Panegírico devem ser lidos nas entrelinhas. (KENNEY, 1982, p. 660)

Ao discursar para o Senado Romano e apresentar sua Gratiarum Actio, Plínio, o Jovem traz em seu texto o discurso de defesa de um governante recém aclamado ao qual ele agradece a indicação como cônsul de uma província e, ao mesmo tempo, traz em seus argumentos o contra discurso presente no enunciado político do período (BONDIOLI; ROSSI, 2018). Esse enunciado é pleno de resistências às práticas políticas do governante Domiciano. Nelson Bondioli, de forma jocosa, mas verdadeira, frequentemente apresenta Domiciano retratado no texto laudatório de Plínio como "aquele que não deve ser nomeado". Concordamos plenamente com essa afirmativa pois retrata exatamente como se dá a presença do último imperador flaviano na fala do senador.

Ao longo do Panegírico, Trajano é imaginado como um exemplo ou referência para futuros imperadores seguirem ou não. Em sua ação laudatória, Plínio não se atreveu a esperar por mais do que "melhor do que o pior", tão sombrias eram as expectativas estabelecidas pelos imperadores anteriores:

44.2 - Pois te portas como príncipe com o juízo de um cidadão privado - e, de fato, o desempenhas melhor do que rogavas que outro o fizesse. Dessa forma, fomos instruídos de modo em que, se antes o maior voto [que fazíamos] era por um príncipe melhor do que péssimo, agora não podemos aceitar um a não ser que seja ótimo.

44.3 - Ninguém é tão [ciente de] ti e tão ignorante de si mesmo que deseje ocupar esse teu lugar após ti. De modo que é mais fácil encontrar alguém que possa sucedê-lo do que [alguém] desejoso de o fazer.

44.4 - Quem, de fato, voluntariamente se submeteria ao peso de tuas responsabilidades? Quem não temeria em ser comparado a ti? Sabes por experiência própria o quão penoso é suceder a um bom príncipe e tinhas a adoção como justificativa.

Os futuros imperadores teriam que escolher entre as viagens frugais de Trajano com contas divulgadas e o exemplo oposto de Domiciano. O juramento de Trajano como cônsul-eleito lhe dá igual glória para que os futuros imperadores pudessem o seguir como exemplo. Claramente a crítica de Plínio, o Jovem à Domiciano, ao elogiar Trajano, traz, em si, elementos políticos e filosóficos relacionando-os ao conflito entre posições políticas entre o estoicismo e o epicurismo como já foi amplamente discutido 
na historiografia. Também ressalta a necessidade de se olhar para o texto laudatório por meio de suas entrelinhas, como também já foi afirmado aqui como a referência de Kenney logo acima.

Além disso, os futuros príncipes, querendo eles ou não, saberão, porém <tanto custou tua viagem> e com esses dois exemplos se recordarão que da mesma maneira os homens farão juízo a respeito de seus hábitos, exatamente a partir do exemplo que escolherem. (Pan., 20.6)

Não só isso, mas enquanto sentado ditava o juramento, ele [Trajano] jurava, pronunciando distintamente cada palavra com as quais, ciente de que se mentisse, consagraria a ira dos deuses à sua pessoa e sua casa. Grandioso, César, e próprio à tua glória, tanto se os príncipes posteriores sigam esse teu exemplo, quanto se não o fizerem. (Pan., 64.3)

Plínio traça o contraste entre a dominatio do passado e o principato do presente, com o refrão recorrente de que se os príncipes continuarem como ele começou, ele fornecerá um modelo para seus sucessores para sempre. Esta é uma propaganda hábil, uma mistura sutil de fato e uma maneira de dizer a Trajano o que seus gratos concidadãos desejavam.

Graças ao Panegírico e a Plínio, o Jovem, o nome optimus sempre será reconhecido como de Trajano: em bons imperadores o nome será de outra pessoa, em ruim, será falso.

Não são justos os motivos pelos quais o Senado e Povo Romano adicionaram a ti o sobrenome de Ótimo? Ordinário, certamente, e comum - no entanto é novo. Sabes que ninguém o merecera anteriormente, e ele não era sequer cogitado se alguém o merecesse.

Seria, por acaso, preferível chamá-lo de Feliz? Esse seria concedido não por tua conduta, mas por tua fortuna. Grande, talvez? O qual atrai mais inveja do que excelência. Um príncipe ótimo o adotou com seu nome e o Senado com o de Ótimo.

Esse nome é a ti tão pessoal quanto o nome paterno, e não o define e o distingue mais quem o designa de "Trajano" do que quem o chama de "Ótimo" - da mesma forma como antigamente eram designados os Pisos por sua frugalidade, os Lélios por sua sabedoria, os Metelos por sua piedade. Todas essas [virtudes] as quais são simultaneamente contidas em seu único nome. E não pode ser [alguém] considerado ótimo a não ser aquele que seja superior em excelência a todos os homens ótimos em cada um dos campos em que eles são louvados.

Pela mesma razão, aquele que é pai dos homens e dos deuses é cultuado pelos nomes primeiro de Ótimo e, segundo, de Máximo. Ainda mais brilhante então teu louvor, que não és menos entendido como ótimo do que máximo. 
Adquiriste o título que a outro não é possível transferir, a não ser de modo a parecer estranho a um bom príncipe e falso a um mau; [título] o qual é possível que todos posteriormente usurpem, porém, sempre reconhecerão sê-lo teu.

E realmente, tal qual o título Augusto incita-nos àquele, ao qual pela primeira vez fora consagrado, assim esse de Ótimo jamais será chamado pela memória humana sem que seja recorrido a ti, e tão frequentemente quanto nossos descendentes considerarem chamar a outro de Ótimo tu serás recordado tu que mereceste assim ser chamado. (Pan., 88.4-10)

Segundo Betty Radice (1968), a mensagem de Plínio, o Jovem teria sido clara desde o início, a autora reforça que talvez fosse compreensível que os seus amigos senadores estivessem ansiosos para ouvir mais elementos laudatórios e de comparação ao seu antecessor.

Os parágrafos iniciais do Panegírico contrastam com o dever desagradável de derramar as palavras lisonjeiras que eram esperadas pelo imperador que era inimigo do Senado com o prazer de expressar a apreciação genuína de um governante verdadeiramente virtuoso:

Quem, mais do que o Cônsul, deveria seguir e observar este costume? Em que momento melhor o observar, senão quando por império do Senado e a autoridade da República nos instamos a dar graças ao ótimo príncipe?

Qual presente dos deuses poderia ser mais excelente ou mais esplêndido do que um príncipe casto, inviolável e tão similar aos deuses?

E se ainda fosse possível duvidar se fora o acaso ou por acidente, ou ainda de alguma forma por um poder divino pelo qual os governantes do mundo foram concedidos, restará evidente que nosso príncipe foi instituído por influência divina.

Não foi, pois, nenhum poder obscuro do destino, mas pelo próprio Júpiter que ele foi revelado aos olhos [de todos] e publicamente: obviamente, foi em meio aos altares e sacrifícios e no mesmo local onde deus faz sua presença sentida, como no céu e nas estrelas, que ele foi eleito.

Por essa razão, é mais apropriado e piedoso que seja rogado a ti, luppiter Optime Maxime, outrora fundador e agora guardião de nosso império, de forma que meu discurso seja digno de um Cônsul, digno do Senado, digno do Príncipe, e que todas as coisas ditas por mim sejam baseadas na liberdade, confiança e na verdade; e que minha ação de graças esteja tão longe de parecer uma adulação quanto esteja longe de parecer uma obrigação. (Pan., 1.2-6)

Plínio, o Jovem pede a Trajano que ocupe o cônsul para ensinar futuros imperadores a desistir de sua preguiça e adiar seus luxos por um tempo, e se presume que (todos) 
futuros imperadores teriam, pelo menos, os vícios imperiais de segunda ordem como a desídia e o apego à opulência, se não os vícios de primeira ordem de arrogância e crueldade. Neste aspecto, as características da humildade (modéstia) e da piedade são vinculadas a Trajano:

Quando tratas de evitar com súplicas os arcos, os troféus e as estátuas, com indulgência concedemos à tua modéstia, pois essas honras são, de fato, dedicadas à tua pessoa. Entretanto, agora demandamos que ensines aos futuros príncipes a renunciar à inércia e a adiar brevemente os deleites. Que ao menos e por um brevíssimo período de tempo eles despertem, por assim dizer, de seu sono de felicidade, que vistam a toga praetexta, a qual tanto podem conceder quanto ocupar. Que eles se sentem sobre a curul que detêm - em resumo, que eles sejam aquilo que foi por eles próprios ardentemente cobiçado e que não desejem ser cônsules somente para tê-lo sido. (Pan., 59.2)

Embora seja o Panegírico sobre o Optimus Princeps, grande parte de seu conteúdo é dedicado a um ataque a Domiciano, que, aos olhos de Plínio, é de fato os pessimus princeps.

E que proeminentíssimo mês a nós atribuíste, o qual o dia de teu nascimento embeleza, quão ilustre para nós! Nós que o celebraremos por édito e com espetáculos, dia esse que contém tripla alegria e prazer, no qual um príncipe péssimo foi removido, um ótimo dado, e o melhor que o ótimo nascido. (Pan., 92.4)

Pois tu já, em outro momento, o recebeste em tua tutela quando o arrancaste das mandíbulas daquele ladrão avidíssimo. E nem, de fato, sem teu auxílio, este lugar - que a todos ultrapassa - se manteria firme enquanto todos os outros eram profundamente chacoalhados. Foi negligenciado por um péssimo príncipe aquele que não poderia ter sido desprezado sob um ótimo. (Pan., 94.3)

Essas referências desfavoráveis ao Domiciano oferecem informações consideráveis sobre o culto imperial sob esse monarca.

Em sua ênfase sobre a fama, glória e sobre as qualidades que fazem de um homem um princeps entre seus companheiros e eventualmente asseguram a ele a imortalidade, Plínio apenas ecoa o melhor pensamento de Cícero. É menos importante ser César e Augusto do que ser melhor do que todos os imperadores, Césares e Augusto. Trajano deveria querer títulos vazios, mas a verdadeira e eterna glória do autocontrole e da moderação. Até o título Optimus, para todas as suas associações religiosas, estava aos olhos de Plínio, o Jovem como elementos senatoriais e civis. Ao se tornar cônsul, Trajano fez o juramento habitual de obedecer às leis, que demostraram que não estão os "princeps supra leges, sed leges supra principem" (HAMMOND, 1938, p. 124). Plínio, o Jovem parece ter em mente o conceito estoico do rei como lei animada quando 
ele afirma. Assim, a vida de Trajano deve ser uma censura constante, pois ele deve governar não tanto através do imperium como pelo seu exemplo.

E nós? É a divindade de nosso príncipe ou seria a sua humanidade, sua moderação, sua condescendência que com amor e alegria leva o mundo inteiro a celebrar, como costumávamos? E agora, há título mais conveniente e adicionado por nós a um cidadão, a um senador, do que aquele de Ótimo? Cuja arrogância dos príncipes anteriores fez para ele [Trajano] um sobrenome, um título pessoal? (Pan., 2.7)

Assim, observamos uma ou duas estátuas suas no vestíbulo de lovi Optimi Maximi - e essas feitas de bronze, enquanto que, até pouco tempo atrás, todas as entradas, todos os degraus, toda a área reluzia a ouro e prata, ou melhor dizendo, estava poluída. Quando as estátuas dos deuses ficavam imundas por estar em meio a estátuas de um príncipe incestuoso. (Pan., 52.3)

Com similar reverência, César, tu não permites que deem graças à tua bondade dirigindo-se a teu Genium, mas sim ao poder de lovis Optimi Maximi. A ele é devido tudo aquilo que nós devemos, e os benefícios que tu fazes são presentes dele que concedeu-te a nós. (Pan., 52.6)

Este tropo, que se repete na carta X.2 que Plínio, o Jovem endereça a Trajano ao receber o direito de quem tem três filhos e na narrativa de adesão do discurso panegírico, tem uma qualidade dinâmica e paradoxal que the permite lidar com alguns dos elementos contraditórios básicos da propaganda imperial, em particular o problema do mal governo imperial.

É, no entanto, interessante observar como Plínio, o Jovem usa os mesmos dispositivos de recusatio e cunctatio, a fim de garantir aprovação prévia para ações que, no curso do longo julgamento à frente, podem ser ofensivas para alguns de seus colegas senadores. E, assim como com o imperador, sua aparente modéstia é elogiada pelo Senado quando ele finalmente aceita o seu papel de governante.

Nesse sentido, de fato, o paralelo entre os optimus civis e optimus princeps não é inapropriado, pois em ambos os casos, a imagem é criada do indivíduo modesto e responsável servindo aos melhores interesses do Estado (NICOLS, 1980, p. 383). De fato, essa ideia de serviço é um componente básico do patrocínio das comunidades e reforça os elementos presentes aos mecanismos do culto imperial e as características de um governante presente em todos os cantos do Império Romano e a representação do Pater Patriae.

Pois te portas como príncipe com o juízo de um cidadão privado - e, de fato, o desempenhas melhor do que rogavas que outro o fizesse. Dessa forma, fomos instruídos de modo em que, se antes o maior voto [que fazíamos] era por um príncipe melhor do que péssimo, agora não podemos aceitar um a não ser que seja ótimo. (Pan., 44.2) 
Sem dúvida, por exemplo, eles foram eleitos - e, de fato, os primeiros - pelo Senado, quando esse buscava os melhores homens para serem postos no comando da diminuição das despesas públicas. E essa razão, precisamente essa razão, é que os introduziu no animo interno de César. (Pan., 62.2)

Quão mais difícil é, pois, dar garantia pelos outros do que de si próprio. Tanto mais louvável que, sendo tu mesmo ótimo, fizeste de todos a tua volta similares a ti. (Pan., 83.3)

Para Hoffer (2006, p. 73), Plínio, o Jovem estabelece que o mundo vivido deveria estar configurado em um mundo ideal governado por um governante ideal e divinamente qualificado, como reiteradamente estabelece a relação de Trajano com Júpiter. No entanto, ressalta que a existência do mal na forma do mau imperador não era simplesmente um fato infeliz, embora inevitável. Era um elemento importante da ideologia oficial, consagrado no tema generalizado de denegrir o imperador anterior. $\mathrm{Na}$ verdade, também encontramos elementos que podem vir a denegrir futuros imperadores, e até mesmo o potencial de denegrir o atual imperador que pode se tornar ruim.

\begin{abstract}
Vós notastes, creio eu, Pais Conscritos, que há muito já não mais escolho aquilo que digo. O propósito, para mim, é de louvar ao príncipe e não às ações do príncipe - pois até mesmo os maus fazem muitas coisas louváveis, [mas um] não pode ser louvado por si mesmo a não ser que seja ótimo (optimus). Assim, não há outra maior glória tua, imperador Augusto, do que quando pela pessoa que lhe rende graças nada é escondido, nada é omitido. (Pan., 56.1)

E no que diz respeito aos testemunhos que nós nos rejubilávamos em pronunciar sobre os mereciam em frente ao príncipe, foi pronunciado pelo [próprio] príncipe. Fizeste deles ótimos, quando como dessa forma os declarara. E eles não tiveram sua própria vida aprovada somente por ti, mas também pelo juízo do Senado, o qual se regozijava em ser não menos honrado por ti do que aqueles que louvavas. (Pan., 71.7)

De fato, a vida dos outros homens, assim como a dos príncipes, mesmo aquela daqueles que se vêem como deuses, a duração de todas elas é breve e frágil. Assim, é apropriado que todo aquele que é ótimo se esforce e se empenhe em ser útil à República mesmo após sua morte, evidentemente por registros de sua moderação e justiça, os quais o cônsul pode estabelecer melhor que qualquer um. (Pan., 78.2)
\end{abstract}

Dion Cássio, no livro 68, reforça vários dos elementos presentes no Panegírico de Plínio, o Jovem, principalmente os aspectos relacionados à dicotomia entre Trajano e Domiciano. No entanto, um elemento se destaca quanto às origens de Trajano e a sua relação com o exército sob o governo de Domiciano. No entanto, Dion Cássio reforça sobre o estado crítico nas relações políticas e militares pouco antes da adoção de 
Trajano por Nerva, quando a guarda pretoriana se amotinou e habilmente transmite a atmosfera inquieta desses momentos cruciais.:

Fazia muito tempo, de fato, que tu merecias ser adotado, mas não saberíamos o quanto o império deveria a ti caso tivesse sido adotado mais cedo. Foi aguardado o momento no qual restaria evidente que não tanto estaria aceitando um benefício, quanto o concedendo. Refugiou-se em teu colo a República abalada, e o Império que desabava por cima do imperador foi transferido a ti pela voz do imperador. (Plínio, Pan., 6,3)

Casperio Aeliano, que havia se tornado comandante dos Pretorianos sob ele, como Domiciano, incitou os soldados a se revoltarem contra ele, depois de induzi-los a exigir certas pessoas para execução. Nerva resistiu a eles com firmeza, até a ponto de mostrar a clavícula e apresentar-lhes a garganta; mas ele não realizou nada, e aqueles a quem Aeliano desejou foram afastados. Nerva, portanto, sentindo-se tão desprezado em razão da velhice, subiu ao Capitólio e disse em voz alta: "Que um bom sucesso participe do senado romano, do povo e de mim. Adoto Marcus Ulpius Nerva Trajano". Posteriormente, no Senado, ele o nomeou César e Ihe enviou uma mensagem escrita com as próprias mãos (Trajano era cônsul da Germânia): "Que os Danaans pelas tuas flechas requitem minhas lágrimas." (Dion Cássio, Hist. Rom., LXVIII, 6.3)

Ele fornece pedaços de informações disponíveis sobre a carreira de Trajano antes de sua adoção, embora Plínio, o Jovem opte por não dizer nada sobre a origem espanhola de Trajano e encubra sobre seu serviço militar sob Domiciano, como ele faz sobre o papel desempenhado pelo exército em trazer sua adoção. Dion Cássio dá uma boa dose de informações específicas sobre o processo eleitoral, as circunstâncias da adoção e adesão de Trajano, e sua aclamação pelo Senado e pessoas. Além disso, o discurso vai muito além de oferecer informações factuais ou um encomium acrítico de Trajano.

Assim, Trajano tornou-se César e depois imperador, embora houvesse parentes vivos de Nerva. Mas Nerva não estimava o relacionamento familiar acima da segurança do Estado, nem estava menos inclinado a adotar Trajano porque este último tinha suas raízes na Hispania em vez de ser italiota ou italiano, na medida em que nenhum estrangeiro detinha anteriormente a soberania romana; acreditava em olhar para a habilidade de um homem e não para sua nacionalidade. Logo após esse ato ele faleceu, tendo governado um ano, quatro meses e nove dias; sua vida anterior àquela época compreendia sessenta e cinco anos, dez meses e dez dias.

\section{(...)}

Trajano era mais conhecido por sua justiça, por sua bravura e pela simplicidade de seus hábitos. Ele era forte no corpo, estando em seu quadragésimo segundo ano quando começou a governar, de modo que em todo empreendimento ele trabalhava 
quase tanto quanto os outros; e seus poderes mentais estavam no auge, de modo que ele não tinha nem a imprudência da juventude nem a lentidão da velhice. Ele não invejou nem matou ninguém, mas honrou e exaltou todos os homens bons sem exceção, e por isso ele não temia nem odiava nenhum deles. Para calúnias, ele deu pouca atenção e não era escravo da raiva. Ele se absteve igualmente do dinheiro dos outros e de assassinatos injustos. Ele gastou vastas somas em guerras e vastas somas em obras de paz; e enquanto fazia muitos reparos urgentemente necessários em estradas e portos e prédios públicos, ele não drenava o sangue de ninguém por nenhum desses empreendimentos. Ele era tão generoso que, depois de ampliar e embelezar o Circo, que havia se desintegrado em alguns lugares, ele simplesmente inscreveu nele uma declaração de que o tornara adequado para o povo romano. Por estas ações, ele teve mais prazer em ser amado do que em ser honrado. Sua associação com o povo era marcada pela afabilidade e seu relacionamento com o Senado por dignidade, de modo que ele era amado por todos e temido por ninguém além do inimigo. Ele se juntou a outros na caçada e nos banquetes, assim como em seus trabalhos e planos e brincadeiras. (...) Educação no sentido estrito Ihe faltava, quando se tratava de falar, mas sua substância que ele conhecia e aplicava; e não havia qualidade que ele não possuísse em alto grau. (...) ele bebeu todo o vinho que queria, mas permaneceu sóbrio, e em sua relação com os meninos não prejudicou ninguém. E mesmo que ele se deleitasse na guerra, mesmo assim ele estava satisfeito quando o sucesso havia sido alcançado, um inimigo amargurado sendo derrotado e seus compatriotas exaltados. Nem o resultado que geralmente ocorre em tais circunstâncias - presunção e arrogância por parte dos soldados - jamais se manifestou durante seu reinado; com uma mão tão firme, ele as governou. (LXVIII, 4-6)

Este relato de Dion Cássio se aproxima sobremaneira das palavras de Plínio, o Jovem em seu Panegírico de Trajano. Pode-se perceber, em suas várias passagens, a clara relação dicotômica e, muitas vezes antagônica, com o seu antecessor Domiciano.

Se, contudo, fosse esse o único modo pelo qual tu serias colocado no leme do bem-estar público, eu estaria próximo a exclamar que o preço não seria tão alto. Corrompeu-se a disciplina do exército, de forma que tu te tornaste seu reparador e corretor. Foi introduzido o péssimo exemplo, de forma que o ótimo a ele fosse oposto. Enfim, forçou-se um príncipe a matar quem ele não queria, de forma que nos fosse dado um príncipe incapaz de ser forçado. (Pan., 6.2)

Que prazer observar o erário silencioso e em paz, como era antes dos delatores! Agora lá é um templo, agora uma verdadeira habitação dos deuses, não mais um spoliarium dos cidadãos, o cruel receptáculo de despojos cruentos e, até então, o único lugar no orbe terrestre inteiro no qual, sob um ótimo príncipe (optimo principe), os bons seriam inferiores aos maus. (Pan., 36.1) 
Além disso, o primeiro dever de um cidadão pio em relação a um ótimo imperador é recriminar aqueles que foram díspares, pois não ama o suficiente os bons príncipes aqueles que não odeiam suficiente os maus. (Pan., 53.2)

Tu reuniste amigos dentre os ótimos e, indubitavelmente, é justo que esses sejam os mais caros ao bom príncipe tal qual foram os mais detestados pelos maus. Tu sabes como são diversas as naturezas do Dominato e do Principado, portanto nenhum outro será mais grato ao príncipe do que aquele que tenha tanto sofrido com um mestre. (Pan., 45.3)

No entanto, uma questão deve ser feita após os vários elementos argumentados até este momento. Assim como Plínio, o Jovem não aborda o cursus honorum de Trajano em seu Panegírico, também é reticente sobre a sua própria trajetória política sob o governo de Domiciano.

Segundo Rex Winsbury (2014, p. 99-100), Plínio não menciona o posto que tivesse ocupado como praefectus aerarum militare mas este cargo é amplamente conhecido por várias inscrições. Plínio, o Jovem teria recebido este cargo por volta do ano 93, após sua função como pretor. Winsbury levanta a hipótese de que Plínio, o Jovem, teria ficado o resto do governo de Domiciano nesta função. O que poderia ter gerado sérios problemas entre o Senador e o Imperador, principalmente no que tange ao erário do exército. Seja pela conivência nos gastos excessivos do Exército ou pela discordância em relação aos espólios. A própria indicação de Plínio, o Jovem como prefeito do erário militar já demonstra que este fazia parte de um grupo de senadores que gozavam da confiança de Domiciano, governante que ajudou a promover a damnatio memoriae.

Após todos os argumentos e demonstrações de construções das imagens de Trajano como o vobernante ideal, como o Optimus Princeps e como o modelo a ser seguido pelos imperadores que o seguissem. Sendo o Panegírico de Trajano uma das fontes mais referenciadas pela historiografia, somado aos relatos de Dion Cássio que se vale de várias fontes literárias e escritas para elaborar a sua História Romana.

Dentre estas fontes que poderiam ter sido a referência de Dion Cássio, se destaca um dos maiores monumentos construídos no fórum romano e que proporcionou amplo conhecimento sobre Trajano e suas realizações bélicas e de governo: o Fórum Romano, a Basílica Ulpia e, o mais importante deles, a Coluna de Trajano.

Portanto, somadas a estas imagens presentes no texto laudatório de Plínio e repetida nas palavras de Dion Cássio, é possível analisar também as representações de Trajano na Coluna: Trajano é retratado na Coluna quase sessenta vezes (57-60 ocorrências; há pelo menos três representações que podem ou não se referir ao imperador). Ele é mostrado rotineiramente no perfil ou na visão de três quartos; apenas na cena 20 I XX ele é mostrado quase de frente. Sua cabeça está sempre nua quando em trajes de batalha, embora ele seja frequentemente mostrado em armaduras (cerca de $50 \%$ das representações). Quando flanqueado por oficiais ou assessores, ele geralmente é 
colocado no meio da composição e geralmente é um pouco mais alto. Ele é mostrado presidindo o sacrifício seis vezes, três vezes com a cabeça coberta por um véu. Ele é visível 19 vezes na principal "fachada" do poço (sudeste), que ficava de frente para a Basílica Ulpia e para a praça do fórum em si, embora a basílica tivesse mascarado esse lado da Coluna daqueles que estavam no fórum.

Alain Gowing (2005, p. 158), no que tange à importância do Fórum de Trajano, reforça que, além da produção literária do Principado no período de Trajano, como Diálogos de Tácito e o Panegírico de Trajano, de Plínio, o Jovem, este espaço "revigora as estruturas que instanciam os seus valores (...) pois os textos e as construções poderiam encontrar novos usos e novos significados para o passado".

\section{Considerações Finais}

Com o objetivo de abordar as imagens literárias sobre o Imperador Trajano, este artigo pretendeu demonstrar como, a partir de uma relação dicotômica e antagônica, a literatura produzida no Principado forjou a imagem de um imperador conhecido na historiografia como o melhor dos imperadores do Principado, perdendo em excelência e referência apenas para Augusto. Por meio de abordagens de alguns autores, principalmente Plínio, o Jovem e Dion Cássio, é possível perceber que a historiografia adota as narrativas que são apresentadas por estes autores, muitas vezes perpetuando as imagens forjadas por aqueles contextos. Não tínhamos a pretensão de desenvolver uma tese sobre as possibilidades alternativas de interpretação, mas apenas arrolar e problematizar como as imagens de Trajano e de Domiciano são construídas em uma relação direta pelos autores aqui elencados. Muitas vezes pela natureza dos gêneros literários e também pelas questões vinculadas às estruturas políticas e sociais que permeiam sua produção.

Poderiam ser somadas às estas a cultura material produzida no mesmo período dos imperadores aqui estudados. No entanto, devido à complexidade de abordagem, optou-se por se ater às abordagens literárias. Apesar desta opção, não se pode deixar de lado que, ao se propor um estudo da Coluna de Trajano e toda a complexidade do Fórum de Trajano, poderiam ser trazidos maiores elementos para a análise das imagens dos dois imperadores, já que um deles, Domiciano, foi condenado à damnatio memoriae. Também poderiam ser trazidas abordagens sobre estudos numismáticos referente aos dois governantes, o que traria mais elementos para tais comparações.

Apesar das várias possibilidades que não foram seguidas durante o percurso deste artigo, conclui-se que, com as abordagens literárias, em muitos momentos percebeuse que ainda é possível seguir caminhos que podem trazer questionamentos para o estudo dos governos de Domiciano e de Trajano. Principalmente em se pensar sobre o não falado por Plínio, o Jovem e o não percebido na documentação por Dion Cássio, autores que são as principais referências sobre os estudos do período trajânico. 


\section{Referências}

BONDIOLI, N. P.; ROSSI, A. L. D. O. C. Príncipes funestos não descansarão em paz: Discursos e resistências políticas no Panegírico de Trajano. In: SILVA, Semíramis Corsi; CAMPOS, Carlos Eduardo da Costa. Corrupção, crimes e crises na Antiguidade. Rio de Janeiro/RJ: Desalinho, 2018. p. 173-192.

BONDIOLI, Nelson de Paiva. Panegírico de Trajano: da Antiguidade ao Presente. Faces da História, v. 4, n. 2, p. 139-150, 2017a.

COSTA, Alex Aparecido. A integração imperial romana sob Trajano na concepção de Plínio, o Jovem. Marechal Cândido Rondon/PR: UNIOESTE. Revista Tempos Históricos, v. 20, p. 70-88, 2016.

GOWING, Alain. Empire and Memory: The Representation of the Roman Republic in Imperial Culture (Roman Literature and its Contexts). Cambridge: Cambridge University Press, 2005.

HAMMOND, Mason. Pliny the Younger's Views on Government. Harvard Studies in Classical Philology. Cambridge (US): Harvard University Press, v.. 49, p. 115-140, 1938.

HOFFER, Stanley E. Divine Comedy? Accession Propaganda in Pliny, "Epistles" 10.1-2 and the "Panegyric". The Journal of Roman Studies. Cambridge: Cambridge University Press, v. 96, p. 73-87, 2006.

KENNEY, E. J. The Cambridge history of classical literature. Latin literature. Cambridge, Cambridge University Press, 1982.

NICOLS, John. Pliny and the Patronage of Communities. Hermes, v. 108, p. 365-385, 1980.

RADICE, Betty. Pliny and the 'Panegyricus'. Cambridge (UK): Cambridge University Press, Greece \& Rome, Second Series, v. 15, n. 2, p. 166-172, 1968.

STADLER, Thiago David. Amizade e virtudes na construção de uma imagem ideal, encontradas no epistolário cruzado entre Plínio, o Jovem e o Imperador Trajano (98 - 117 d.C.). Revista Vernáculo, Curitiba, n. 21-22, p. 244-251, 2008.

WATERS, K. H. Traianus Domitiani Continuator. The American Journal of Philology. Philadelphia (US): Johns Hopkins University Press, v. 90, n. 4, p. 385-405, 1969.

WINSBURY, Rex. Pliny, the Younger: a life in the roman letters. Londres;Nova lorque: Bloomsbury, 2014.

\section{Fontes}

CASSIUS, Dio. Roman History. Edited and translated by Ernest Cary. Cambridge: Harvard University Press, 1925.

CHRYSOSTOM, Dio. Discourses. Translated by J. W. Cohoon. Cambridge: Harvard University Press, 1939. 
PLINY THE YOUNGER. Letters. Edited and translated by William Melmoth. Cambridge: Harvard University Press, 1958.

SUETONIUS. The Lives of the Caesars. Edited and translated by J. C. Rolfe. Cambridge: Harvard University Press, 1914.

BONDIOLI, Nelson de Paiva. Panegírico de Trajano de Plínio, o Jovem. ed. bilíngue. Curitiba: Editora Prismas, 2017b.

Andrea Lúcia Dorini de Oliveira Carvalho ROSSI é docente de História Antiga do Departamento de História da Faculdade de Ciências e Letras de Assis, Câmpus da Universidade Estadual Paulista "Júlio de Mesquita Filho". Especialista em Principado Romano, mais especificamente no Século I de nossa Era. Dentre suas publicações, destacam-se: As Cartas de Plínio, o Jovem: tradução parcial do Livro X - correspondência administrativa entre o Imperador Trajano e Plínio, o Jovem (São Leopoldo, UNISINOS: 2017) e Príncipes funestos não descansarão em paz: discursos e resistências políticas no Panegírico de Trajano (São João do Meriti - RJ: Desalinho, 2018).

\section{Editores}

Paulo Cesar Gonçalves e Valéria dos Santos Guimarães
Submissão: 31/05/2020

Aceite: 13/08/2020 